\title{
Retinoic acid liposome-hydrogel: preparation, penetration through mouse skin and induction of F9 mouse teratocarcinoma stem cells differentiation
}

\author{
Hongmei $\mathrm{Xia}^{1, *}$, Yongfeng Cheng ${ }^{2}$, Yinxiang $\mathrm{Xu}^{3}$, Zhiqing Cheng ${ }^{1}$ \\ ${ }^{I}$ College of Pharmacy, Anhui University of Chinese Medicine, Hefei, People's Republic of China, ${ }^{2}$ School of Life Science, \\ University of Science and Technology of China, Hefei, People's Republic of China, ${ }^{3}$ Zhaoke (Hefei) Pharmaceutical Co. Ltd , \\ Hefei, People's Republic of China
}

\begin{abstract}
Retinoic acid (RA), a metabolite of retinol, is one of the most biologically active forms of retinoid and plays vital roles in embryonic development and in the regulation of cell proliferation and differentiation. Knowing that liposomes simulate cell membranes and that hydrogel is an ideal delivery vehicle for topical medicine, liposome-hydrogel is a novel preparation that has synergistic advantages over each component separately. Our objective was to investigate the characteristics of RA liposome-hydrogel. For quality control of the RA-loaded liposomes, we measured their morphology, particle size, Zeta-potential, and entrapment efficiency. Then we determined the viscosity of RA liposome-hydrogel. Next, the diffusion through mouse skin was explored, followed by investigation of the mRNA expression levels of Ker18, REX1, and $\alpha$-FP using Q-PCR. The results showed that RA liposome-hydrogel penetrates the mouse skin effectively. The permeation rates were: $\mathrm{Q}_{\mathrm{n}}(\%)$ of RA liposome-hydrogel $<\mathrm{Q}_{\mathrm{n}}(\%)$ of RA-loaded liposome $<\mathrm{Q}_{\mathrm{n}}(\%)$ of RA. The mRNA expression levels were dose-dependent and the effective dose decreased between vehicles due to their different release rates. F9 mouse teratocarcinoma stem cells were an ideal model to explore the mechanism of RA liposome-hydrogel in stem cell differentiation.
\end{abstract}

Uniterms: Retinoic acid (RA). RA liposome-hydrogel/characteristics. RA liposome-hydrogel/preparation. RA liposome-hydrogel/diffusion/experimental study. F9 cell/differentiation.

O ácido retinóico (RA) é um metabolito de retinol. Ele também é uma das formas mais biologicamente ativas de retinóide. Desempenha papel vital no desenvolvimento embrionário e na regulação da proliferação e diferenciação celular. Sabendo-se que lipossomas simulam a membrana das células e que hidrogel é um sistema ideal para o medicamento tópico, o lipossoma-hidrogel é uma nova preparação, que apresenta vantagens sinérgicas em relação a cada um dos componentes separados. Nosso objetivo foi investigar as características de RA lipossoma-hidrogel. A fim de controlar a qualidade do lipossoma carregado com RA, medimos morfologia, tamanho das partículas, potencial zeta e eficiência de retenção. Em seguida, determinou-se a viscosidade de RA lipossoma-hidrogel. Em seguida, avaliou-se a sua difusão através da pele de camundongos, seguida da investigação dos níveis da expressão de mRNA de Ker18, REX e de $\alpha$-FP, utilizando-se Q-PCR. Os resultados mostraram que RA lipossoma-hidrogel pode penetrar na pele do camundongo de forma eficaz. As taxas de permeação foram: Qn (\%) de RA lipossoma-hidrogel $<$ Qn $(\%)$ de lipossoma RA- carregado $<$ Qn (\%) de RA. Os níveis de expressão de mRNA foram dependentes de dose e a dose efetiva diminuiu entre os veículos devido às diferentes taxas de liberação, As células estaminais de teratocarcinoma F9 de camundongo mostraram-se como modelo ideal para explorar o mecanismo de diferenciaçãode células tronco pelo RA lipossoma-hidrogel.

Unitermos: Ácido retinóico (RA). RA lipossoma-hidrogel/características. RA lipossoma-hidrogel/ preparação. RA lipossoma-hidrogel/difusão/estudo experimental. Células F9/diferenciação.

*Correspondence: Hongmei Xia. College of Pharmacy. Anhui University of Chinese Medicine. Hefei - 230038. People's Republic of China. E-mail: sm_shine@163.com 


\section{INTRODUCTION}

Liposome-hydrogel is a combination of two organic formulations - liposome and hydrogel. The liposomal delivery system is composed of biomaterials such as soybean phospholipid, lecithin, cephalin, and cholesterol. It can form phospholipid bilayer membranes through self-assembly. It is a biomaterial preparation often selected as a good model of bio-membrane simulation (Fujisawa, Atsumi, Kadoma, 1989) It can penetrate body barriers such as the blood-brain barrier (Aviral et al., 2009), gastric mucous membrane (Fricker et al., 2010), intestinal mucous membrane (Goto et al., 2006), and cell membrane (Hossain et al., 2006). It can target special cells including cancer cells (Gabizon, Shmeeda, Barenholz, 2003) and brain cells (Dodu, Rotari, Vazques, 2012). Then it accumulates the drugs in the target region to reach and maintain the effective concentration by slow release of drugs from the liposomes. So it is also regarded as a slowrelease preparation. Drugs such as shikonin enveloped into liposomes could be released slowly (Xia et al., 2013).

Liposomes in the nanometer size range can penetrate small capillaries and be taken up by the cells, thereby allowing an efficient drug accumulation in the target tissues and sustained drug release over a period of days or even weeks after administration. In addition, the sterical stabilization by incorporation of polyethylene glycol (PEG) into the bilayer membranes mediated long circulation half-lives of about $16 \mathrm{~h}$ in mice or rats, and $24 \mathrm{~h}$ or longer in humans after i.v. administration (Allen, 1994). All of the above-mentioned liposomes could be used as controlled delivery systems (Mumper, Hoffman, 2000).

Hydrogel is an ideal delivery vehicle for topical medicine. It forms a macromolecular network system, with uniform drug dispersal and adheres closely to skin or mucous membrane, using hydration and interaction. It is beneficial for topical drugs release and constitutes a novel preparation for drug administration to skin, eye mucosa, nasal cavity, and other locations, as seen in studies such as ciprofloxacin hydrochloride release from poloxamerbased ocular hydrogel formulations (Mansour et al., 2008), paeonol and ondansetron nasal gel adhesion and thermal stability (Bhalerao et al., 2009; Chen et al., 2009), and penetration through mouse skin and the associated release kinetics (Panigrahi et al., 2006).

Liposome-hydrogel systems can offer synergistic advantages such as increasing the drug affinity of the mucous membrane of the skin, eyes, gastrointestinal tract, and other areas. The drug bioavailability in the liposomehydrogel system would be improved. Therefore, in this study we applied the liposome-hydrogel system to deliver anti-cancer drugs to penetrate cancer cells.

RA is a member of the most biologically active forms of retinoid. It is an anti-cancer drug that induces cell differentiation and suppresses cell growth in a wide spectrum of cancer cell lines. The mechanisms of anticancer effects underlying RA appear to be associated with its ability to modulate cell differentiation, growth, and apoptosis, thereby preventing angiogenesis. (Vivaldi et al., 2009). These actions are mediated by nuclear retinoid receptors (RARs). RARs are expressed in F9 mouse teratocarcinoma stem cells. The RA response is mediated by two families of nuclear receptors that function as ligand-dependent RAR transcription activators (Laudet, Gronemeyer, 2002). RARs regulate specific subsets of target genes during RA-induced differentiation of F9 mouse teratocarcinoma stem cells (Dan, Gudas, 2008).

However, oral treatment with RA is associated with a progressive decrease in plasma concentrations over time, leading to relapse of the disease and retinoid resistance (Muindi et al., 1992) because the lower drug concentrations are no longer able to sustain the differentiation effects on the cancer cells in vivo. To maintain the biological activity of RA, liposome-hydrogels might be a good choice. The RA liposome-hydrogel is a biocompatible drug carrier. As is the case for many other toxic drugs, encapsulation of RA in the liposome-hydrogel has been shown to decrease its toxic effects, sequester RA at target locations, and amplify its therapeutic effect (Weinstein, Leserman, 1984). RA incorporated in the liposome-hydrogel has reduced in vitro toxicity and retained its full biological activity (Parthasarathy et al., 1994). Furthermore, the liposomehydrogel may protect RA from the catabolic enzymes of the target cells, thus exposing the target cells to the active form of RA for longer periods (Parthasarathy, Mehta. 1998).

F9 mouse teratocarcinoma stem cells belong to the family of embryonic carcinoma stem cells. They resemble the pluripotent mass cells of mouse blastocysts. Possessing many properties of embryonic stem (ES) cells, F9 cells can differentiate into primitive endoderm cells in monolayer cultures or into proximal (visceral) endoderm cells in the aggregation culture when they contact RA. Therefore, the mouse F9 cell is a perfect model system to investigate the mechanism of RA liposome-hydrogel in cell differentiation and cell growth control, and in the biochemical basis of early embryonic development (Jiao, Li, Chiu, 2012).

Currently no paper has reported about retinoic acid (RA) liposome-hydrogel. Therefore, it is valuable to investigate RA liposome-hydrogel thoroughly for wide future application. 


\section{MATERIAL AND METHODS}

\section{Material}

RA was bought from Sigma (St Louis, MO, USA). Soybean phospholipid and cholesterol were purchased from the Sinopharm Chemical Reagent Co. Ltd., China. Carbomer 940 was purchased from the Saipu Macromolecule Material Co. Ltd., China. Dulbecco's Modified Eagle's Medium (DMEM), $\alpha$-Minimum Essential Medium $\alpha$ ( $\alpha$-MEM), Ham's F12 medium, and Fetal Bovine Serum (FBS) were bought from the GIBCO Co. All other chemicals and solvents were of analytical reagent grade.

\section{Cell culture}

Undifferentiated F9 mouse teratocarcinoma stem cells (ATCC, USA) were cultured in the $\alpha$-MEM containing $10 \%$ FBS, $1 \mathrm{mM}$ glutamine and antibiotics (100 mg streptomycin $/ \mathrm{mL}$ and $100 \mathrm{U}$ of penicillin/mL).

For the experiments involving cell differentiation into visceral endoderm, F9 mouse teratocarcinoma stem cells were seeded at $1 \times 10^{6}$ cells $/ 190 \mathrm{~mm}$ bacteriological petri dish maintained in a 1:1 mixture of DMEM and Ham's F12 medium supplemented with 10\% FBS, 1 mM glutamine, and antibiotics (100 mg streptomycin/mL and $100 \mathrm{U}$ of penicillin $/ \mathrm{mL}$ ). The cells were cultured in the presence of $50 \mathrm{nM}$ RA, RA-loaded liposome, or RA liposome-hydrogel for seven days. The morphological and gene expression changes were investigated.

\section{Preparation of RA liposome-hydrogel (RA-L-G)}

\section{RA-loaded liposomes (RA-L)}

RA-L was prepared according to the procedure described in our previous reports (Xia et al., 2013). $3 \mathrm{mg}$ RA, $100 \mathrm{mg}$ soybean phospholipid, and $20 \mathrm{mg}$ cholesterol were dissolved in $10 \mathrm{~mL}$ dehydrated alcohol. The mixture was aspirated using a syringe and injected into $10 \mathrm{~mL}$ phosphate-buffered saline (PBS, $8 \mathrm{~g} \mathrm{NaCl}, 0.2 \mathrm{~g} \mathrm{KCl}, 1.44$ $\mathrm{g} \mathrm{Na}_{2} \mathrm{HPO}_{4}$, and $0.24 \mathrm{~g} \mathrm{KH}_{2} \mathrm{PO}_{4}$ dissolved in $1 \mathrm{~L}$ distilled water, $\mathrm{pH} 7.4)\left(60 \pm 5^{\circ} \mathrm{C}\right)$. The final concentration of RA-L was $1 \mathrm{mM}$. Blank control samples were prepared using the same method without RA. After vaporizing the alcohol, the solution was filtrated using a membrane (pore size of $0.22 \mu \mathrm{m})$.

\section{RA liposome-hydrogel (RA-L-G)}

RA-L-G was prepared by dissolving $1.0 \mathrm{~g}$ carbomer 940 powder in $100 \mathrm{~mL}$ phosphate-buffered saline containing RA-L. The solvent was allowed to swell at room temperature overnight. Then we added $10 \% \mathrm{NaOH}$ and adjusted the $\mathrm{pH}$ of the solvent to about 7.0 to allow formation of the transparent hydrogel.

\section{Particle size and Zeta-potential measurement}

The RA liposomal formulation was diluted with PBS and put into the sample cells of the Zeta potentiometer (Brookhaven instrument corporation) to measure the particle size and Zeta-potential and ultimately to analyze the formulation using the ZetaPlus particle sizing software. All measurements were performed immediately after liposome preparation.

\section{Entrapment efficiency determination using the traditional dialysis method}

Solutions with different concentrations of RA $(0.3,0.6,0.9,1.2,1.5$, and $1.8 \mu \mathrm{M})$ were prepared in dehydrated alcohol. The absorbance of each solution was determined by UV/Vis spectrophotometry (DU730, Beckman, America) at the characteristic wavelength of RA (347 nm). The calibration curve of RA $(A=0.5017 \mathrm{C}$ $+0.0321(\mathrm{r}=0.9999))$ was followed. The detection limit of RA was $0.3 \mu \mathrm{M}$. The degree of precision was excellent ( $\mathrm{RSD}=1.02 \%$ ). The RA solutions were stable for two hours $(\mathrm{RSD}=0.85 \%)$.

The entrapment efficiency of RA-L was estimated according to the calibration curve. $1 \mathrm{~mL}$ of each liposomal suspension in PBS was suspended in $10 \mathrm{~mL}$ dehydrated alcohol, followed by vigorous spinning for $10 \mathrm{~min}$, to destroy the liposome structure, releasing RA into the organic phase. Absorbance of the organic phase was measured and the total amount of $R A\left(Q_{\text {total }}\right)$ was calculated. Another $1 \mathrm{~mL}$ of each liposomal suspension in PBS was dialyzed adequately and the amount of RA that was not incorporated into the liposomes $\left(\mathrm{Q}_{\text {out }}\right)$ was calculated. Then the entrapment efficiency was calculated according to the following equation:

$$
\text { Entrapment Efficiency }(\%)=\left(\mathrm{Q}_{\text {total }}-\mathrm{Q}_{\text {out }}\right) / \mathrm{Q}_{\text {total }} \times 100
$$

\section{Viscosity determination}

We studied the rheological behavior of our manufactured RA-L-G by alteration of shear rate. A rotating cylinder viscometer (NDJ-8S, China) was used. The viscosity of the hydrogel was measured under room temperature, at shear rates of about $60.0 \mathrm{r} / \mathrm{min}$ with rotor $2^{\#}$. 


\section{Passage through the mouse skin in vitro}

\section{Built mouse skin membrane in vitro}

The mouse (ICR, $20 \pm 2 \mathrm{~g}$ ) was anesthetized by injection of $20 \%$ urethane solution into the peritoneal cavity $(0.1 \mathrm{~mL} / 10 \mathrm{~g})$. The mouse skin was carefully shaved and then removed. The blood vessels could be observed clearly. The separated mouse skin membrane was thoroughly washed in isotonic PBS (pH 7.4) and used at once.

All experimental procedures were approved by the Institutional Animal Care and complied with the requirements of the National Acts on the use of experimental animals (People's Republic of China).

\section{The permeate studies of RA, RA-L and RA-L-G}

The studies of RA, RA-L, and RA-L-G permeation through the mouse subcutaneous mucous were conducted in a Franz-type diffusion cell at $37^{\circ} \mathrm{C}$ with a diffusional area of $1.12 \mathrm{~cm}^{2}$. First, PBS buffer (pH 7.4) was added into the receiver chamber $(25.5 \mathrm{~mL})$. Teflon-coated magnetic beads were used in the receiver chamber to stir continuously. The mouse skin membrane was clampmounted between the donor and receiver chambers of the diffusion cell. Before the start of the experiment, the membrane was equilibrated for $1 \mathrm{~h}$ with PBS buffer $(\mathrm{pH}$ 7.4) at $37^{\circ} \mathrm{C}$. For the permeation study, $1 \mathrm{~mL}$ of RA, PA-L, and RA-L-G were added into the donor chamber of the diffusion cell, in close contact with the mouse skin membrane. The permeation experiments were performed for $2880 \mathrm{~min}$. $100 \mu \mathrm{L}$ samples were taken from the receiver chambers. The amount of RA permeated was determined at time intervals of $30,60,120,180,240,300,360,540,720$, 1440,2160 and $2880 \mathrm{~min}$ by UV/Vis spectrophotometry (DU730, Beckman, America). The permeability rate was then determined.

\section{RA-L-G regulated the expression level of Ker18, REX1, $\alpha-F P$}

\section{The mRNA isolation and $c D N A$ synthesis}

Total cellular mRNA was extracted from untreated F9 cells (control) or treated F9 cells with RA, RA-L, or RA-L-G according to the TRIZOL protocol. The quality of the mRNA was tested in $2.0 \%$ agarose gel stained with ethidium bromide (EB). The mRNA concentration was measured using a spectrophotometer.

For first strand cDNA synthesis, $1 \mu \mathrm{g}$ total RNA was used according to the protocol of the M-MLV reverse transcriptase (Reverse Transcription System, Promega Co.): (1) We added $1 \mu \mathrm{g}$ total mRNA, $1 \mu \mathrm{L}$ Oligo(dT) ${ }_{15}$
Primer, and $17 \mu \mathrm{L}$ DEPC $\mathrm{H}_{2} \mathrm{O}$ to the PCR tubes, which were held at $70{ }^{\circ} \mathrm{C}$ for $5 \mathrm{~min}$. Then we took the tubes out immediately and put them onto ice for $5 \mathrm{~min}$. (2) We built the $25 \mu \mathrm{L}$ reaction solution using the mixed solution above plus $5 \mu \mathrm{L} 5 \times$ Reverse Transcription Buffer, $1.25 \mu \mathrm{L} 10 \mathrm{mM}$ dNTP Mixture, $0.75 \mu \mathrm{L}$ RNase Inhibitor $(40 \mathrm{U} / \mu \mathrm{L})$, and $1 \mu \mathrm{L}$ M-MLV Reverse Transcriptase, $25 \mathrm{U} / \mu \mathrm{L}$ ). (3) We put the $25 \mu \mathrm{L}$ reaction solution into the PCR instrument at $42{ }^{\circ} \mathrm{C}$ for $60 \mathrm{~min}$, then at $70^{\circ} \mathrm{C}$ for $15 \mathrm{~min}$. (4) The first strand cDNA was synthesized and stored at $-20^{\circ} \mathrm{C}$.

\section{Q-PCR}

After reverse-transcription (RT), the quantitative polymerase chain reaction (Q-PCR) was performed with our primary RT reaction product cDNA to determine Ker18, REX1, and $\alpha$-FP gene expression. All actions were carried out in translucent, flat-bottom, 96-well plates. It was a $20 \mu \mathrm{L}$ PCR action system. cDNA was diluted 12 times and we took out $4 \mu \mathrm{L}$ as the template. Then $3 \mu \mathrm{L}$ upstream primer, $3 \mu \mathrm{L}$ downstream primer, and $10 \mu \mathrm{L}$ SYBR ${ }^{\circledR}$ Green Real-time PCR Master Mix (No. QPK-201, Toybo Co., Ltd., Osaka, Japan) were mixed. Q-PCR amplification was initiated in a 7300 real-time PCR instrument (ABI Co.) with 10 min of denaturation at $95^{\circ} \mathrm{C}$ followed by 40 cycles at $95^{\circ} \mathrm{C}$ for $15 \mathrm{sec}, 60^{\circ} \mathrm{C}$ for $1 \mathrm{~min}$. Three parallel reactions were done for each sample.

The primer sequences for Ker18: Sense: 5'-AGA TGG AGC AGC TCA ATG-3'

Antisense: 5'-GTT TGC ATG GAG TTG CTG-3'

The primer sequences for REX1: Sense: 5'-ATG GAC TAA GAG CTG GG-3'

Antisense: 5'-CTT GAA CAA TGC CTA TGA CT-3'

The primer sequences for $\alpha$-FP: Sense: $5^{\prime}$-ACC TCA GCA GAG CTG ATC GA-3'

Antisense: 5'-TTG CAG CAG TGG CTG ATA CCA -3'

The primer sequences for $\beta$-actin: Sense: 5'- GTGGGGCGCCCCAGGCACCA-3'

Antisense: 5'- CTCCTTAATGTCACGCACGATTTC-3'

Specificity was determined for each reaction from the dissociation curve of the PCR product. This dissociation curve was obtained by following the SYBR Green fluorescence level during gradual heating of the PCR products from $60^{\circ} \mathrm{C}$ to $95^{\circ} \mathrm{C}$.

Relative quantification of each gene expression level was normalized according to $\beta$-actin gene expression. Relative mRNA expression was generated using the $2-\Delta C T$ method. First, the transcription level of the specific gene in different samples was normalized using the formula $\Delta \mathrm{Ct}$ (specific gene $)=\mathrm{Ct}$ (specific gene $)-$ 
$\mathrm{Ct}$ ( $\beta$-actin). We chose the minimum value of $\Delta \mathrm{Ct}$ as the standard. Finally, we calculated the relative mRNA according to the formula of $100 \times 2-[\Delta \mathrm{Ct}$ (specific gene) $-\Delta \mathrm{Ct}$ (specific gene) the lowest level].

\section{Statistical analysis}

All values were expressed as mean $\pm \mathrm{SD}$. Differences in the treatments were expressed as means and compared statistically using least significant differences (LSD) at the $5 \%$ level using the one-way ANOVA test with SPSS 13.0 software.

\section{RESULTS}

\section{RA-L}

We observed the bigger segments, visible through the microscope and obtained before filtration using the $\Phi 0.22 \mu \mathrm{m}$ membrane. RA-L was identified by its double phospholipid membrane. Retinoic acid is almost insoluble in water and it is supposed to be intercalated into the lipid bilayer (Figure 1). They simulated the cellular phospholipid membrane.

\section{Particle size, Zeta-potential, entrapment efficiency and viscosity}

The particle size of RA-L was $137.9 \pm 16.1 \mathrm{~nm}$. The Zeta-potential of the particles was $-32.54 \pm 4.64 \mathrm{mV}$. The entrapment efficiency of RA-L was $79.81 \pm 9.63 \%$ determined by the traditional method of dialysis. The viscosity of RA-L-G was $7.25 \pm 1.23 \mathrm{~Pa} \cdot \mathrm{s}$.

\section{The permeation rate of RA, RA-L, RA-L-G in vitro}

The cumulative permeation rate $\mathrm{Q}_{\mathrm{n}}(\%)$ was calculated according to the following equation:

$$
\mathrm{Q}_{\mathrm{n}}(\%)=\frac{\left(C_{n} V_{n}+\sum C_{i} V_{i}\right)}{C_{R A / R A-L / P A-L-G} V_{R A / R A-L / R A-L-G}} \times 100 \%
$$

where $\mathrm{C}_{n} \mathrm{~V}_{\mathrm{n}}$ was the quantity of RA in the receiver chamber; $\mathrm{C}_{\mathrm{i}} \mathrm{V}_{\mathrm{i}}$ was the quantity of RA removed for determination; and $\mathrm{C}_{\text {RA/RA-L/RA-L-G }} \mathrm{V}_{\text {RA/RA-L/RA-L-G }}$ was the total quantity of RA, RA-L, or RA-L-G in the donor chamber. $\mathrm{Q}_{\mathrm{n}}(\%)$ of RA, RA-L, and RA-L-G in vitro at $2880 \mathrm{~min}$ were $50.25 \pm 5.75 \%, 22.56 \pm 3.42 \%$, and $12.59 \pm 2.83 \%$ (Figure 2). The results at $2880 \mathrm{~min}$ showed $\mathrm{Q}_{\mathrm{n}}(\%)$ between RA and RA-L; RA and RA-L-G had statistical significant

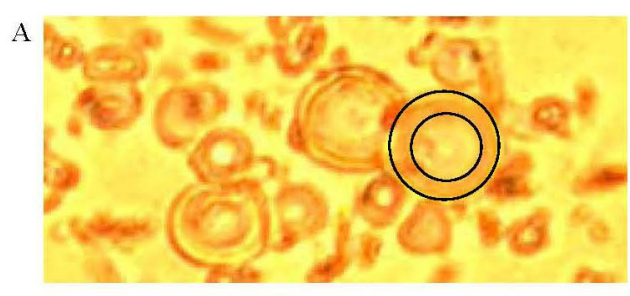

B
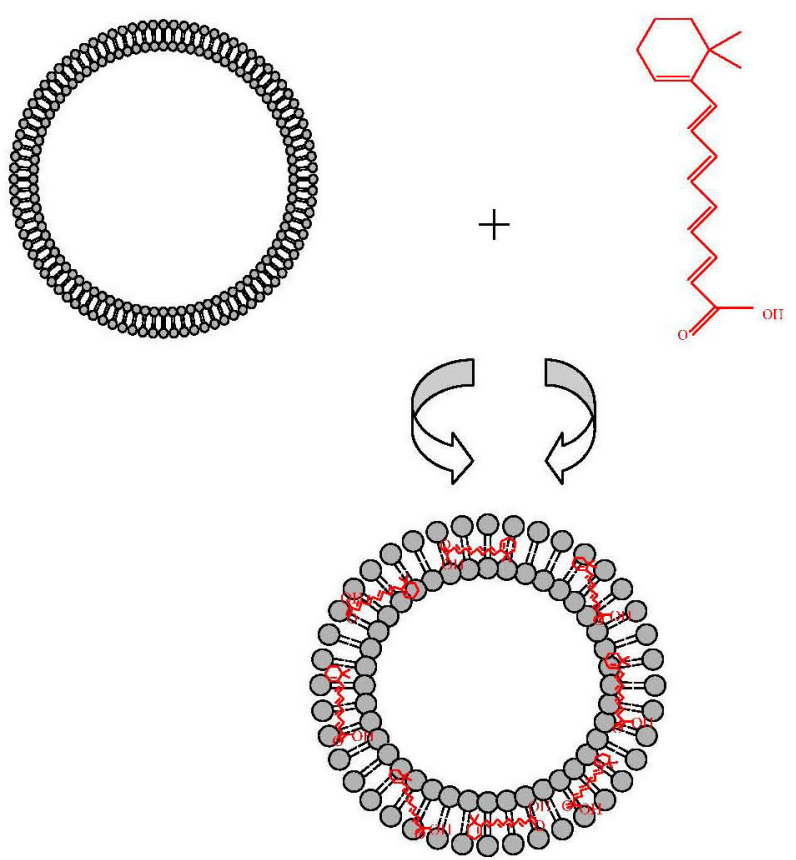

FIGURE 1 - RA-L with its double phospholipid membrane. A. The double phospholipid membrane was observed through the microscope (400x). B. The schematic diagram of the liposomes. Retinoic acid is almost insoluble in water and it is supposed to be intercalated into the lipid bilayer

difference $(P<0.01 * *) ; \mathrm{Q}_{\mathrm{n}}(\%, 2880 \mathrm{~min})$ between RA-L and RA-L-G had significant difference.

$Q_{n}(\%)$ of RA-L-G was lower than that of RA-L and RA. $Q_{n}(\%)$ of RA-L-G, RA-L and RA increased progressively, indicating that the liposome-hydrogel could release RA slowly. Therefore, liposome-hydrogel improved RA bioavailability because of its slow and controlled release, suggesting a valuable clinical application in anti-cancer treatment.

\section{Differentiation of F9 mouse embryonal teratocarcinoma stem cells}

Using standard methods for inducing F9 cell differentiation, the cells were grown in suspension in bacteriological Petri dishes in medium containing 50nM 


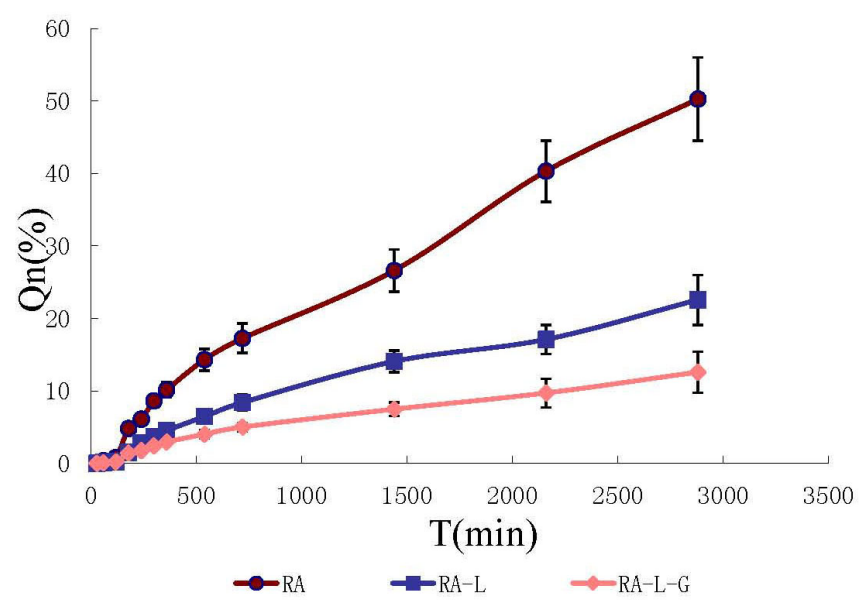

FIGURE 2 - The permeation curves of RA, RA-L, and RA-L-G.

RA as shown in Figure 3. The cells aggregated to form embryonic bodies with a ring of outer cells that resembled visceral endoderm cells. After induction of F9 cell differentiation with RA, RA-L, and RA-L-G for a period of time, these outer layers of the embryonic bodies became rough, while the F9 cell aggregate grown in suspension under the same condition without RA treatment had a smooth surface. This morphologic change of F9 cell aggregates indicated that RA, RA-L, and RA-L-G induced F9 cell differentiation.

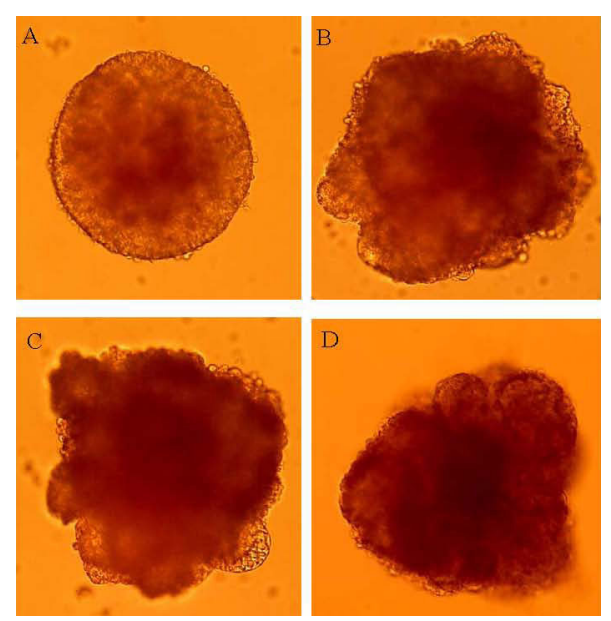

FIGURE 3 - Induction of F9 cell differentiation with RA, RA$\mathrm{L}$, and RA-L-G for seven days. A is the control, B is RA, C is RA-L, and D is RA-L-G.

The expression level of $\alpha$-AFP, Ker18, and REX 1 in F9 mouse embryonal teratocarcinoma stem cells with RA, RA-L, and RA-L-G treatment

To further describe F9 mouse embryonal teratocarcinoma stem cells, we detected the mRNA expression of Ker18, REX1, and $\alpha$-AFP by Q-PCR after seven days of treatment with RA, RA-L, and RA-L-G. The dose-dependent results are shown in Figure 4. The effective dose decreased progressively (RA>RA-L> RA-L-G) because of their different release rate.

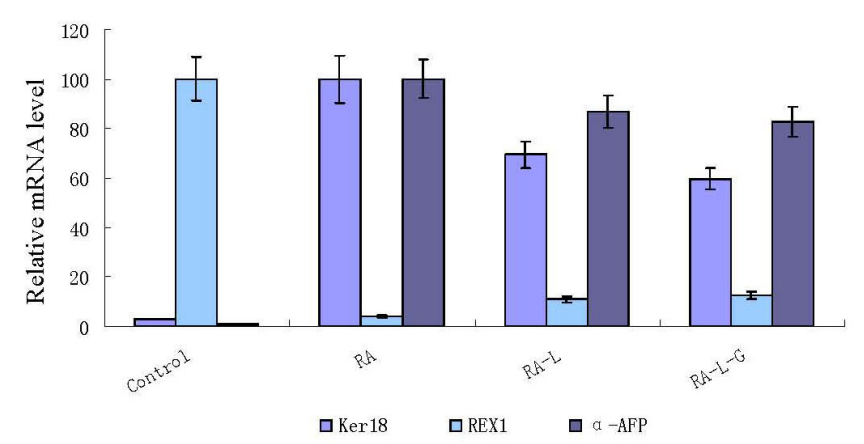

FIGURE 4 - The effect of RA, RA-L, and RA-L-G on the mRNA expression of Ker18, REX1, and $\alpha$-AFP in F9 mouse embryonal teratocarcinoma stem cells.

\section{DISCUSSION}

RA is a biologically active molecule related to vitamin $\mathrm{A}$. It is one of the endogenous compounds that mainly controls the growth and differentiation of some special tissues. Specifically, RA has an effect on the growth and differentiation of malignant cells. It has been used for the chemoprevention and chemotherapy of various types of cancer, such as promyelocytic leukemia (Meng-er et al., 1988), acute cervical cancer (Lippman et al., 1992), and metastatic squamous cell cancers of the skin (Lippman et al., 1992), as well as in breast, lung, head, neck, renal, and prostate cells (Sun, Lotan, 2002). It has evoked our interests in exploring RA as a therapeutic agent for cancer treatment.

RA induces F9 mouse teratocarcinoma stem cells to differentiate into primitive endoderms and further into visceral and parietal endoderms, depending on the culture conditions. Primitive and visceral endoderms show epithelium-like properties during mammalian development. RA up-regulates the expression of differentiation markers for primitive, visceral, and parietal endoderm in F9 cells (Inoue et al., 2009). F9 mouse teratocarcinoma stem cells increase the expression of Ker18 in response to RA to differentiate into primitive endoderm. The mRNA levels of Rex1 are high in F9 stem cells and reduced during RA-induced differentiation (Hosler et al., 1989). Thus, Rex1 is a marker of undifferentiated F9 mouse teratocarcinoma stem cells. Further differentiation of F9 mouse teratocarcinoma stem cells occurs along two pathways depending on the 
culture conditions. After forming aggregates, the cells can differentiate into visceral endoderm, as indicated by the expression of a unique marker, $\alpha$-fetoprotein $(\alpha-F P)$ (Young, Tilghman, 1984). So Ker18, Rex1, and $\alpha$-FP were chosen as the important indicators to investigate RA-induced cell differentiation.

Liposomes have bilayer lipid membranes that resemble cell membranes. It is well known that phospholipids composing most biological membranes are in their liquid-crystalline state under physiological conditions and this plays a major role in the control of membrane-mediated functions (Jemiola-Rzeminska et al., 2005). Moreover, liposomes have some special important properties. They can be nontoxic, long-lasting, slow-release, biocompatible with drugs, and inert toward many drugs. Additionally, they can decrease the toxicity of drugs, target lymph tissue, and increase the solubility and stability of drugs (Coimbra et al., 2011). Such properties make liposomes a suitable biomaterial for controlled drug release systems.

Indeed, to comply with the rapidly increasing demands in medical treatment and health care, various kinds of liposomes have been made and tested so far. Based on recent progress in organic synthesis techniques, these liposomes could target special tissue exactly, including brain, cancer, and others. For example, to improve the targeting on specific tumors, methods for modifying the surface of liposomes with anti-smooth-muscle cell actin (Laing et al., 2010), antibody anti-EGFR antibodies (Kim et al., 2009), and anti-VEGF antibody (Tirand et al., 2006), as well as folate (Zhang et al., 2004), have been adopted in the experiments.

When the liposomes were put into the hydrogel, they formed liposome-hydrogel, with novel characteristics and advantages. How does the liposome-hydrogel interact with the target cells? Once the liposome-hydrogel contacts the cells, the liposome might first diffuse and escape from the networks of the hydrogel. Then the liposome membrane might fuse with that of the cells. The drug would release from the liposomes across the membrane into the target cells. Wong et al. (2007) tried to investigate and analyze the moment of membrane fusion using urchins and eggs. The behavior of the liposomes with the membranes of cells such as cancer cells is important. Liposome behavior is closely related to the release of the drugs and is affected by many factors. Changes in the fluidity of the membrane cause changes in membrane permeability. Because of the trans-membrane concentration gradient, the liposomeencapsulated drug moves by bulk diffusion into the cancer cells, forming a higher concentration of the drug at the target site, resulting in a strong killing effect on the cancer cells. Therefore, the goal of local chemotherapy is achieved.

\section{CONCLUSION}

We investigated the preparation and characteristics of RA-L-G. The diffusion of RA-L-G across the mouse skin was also explored. The Qn (\%) of RA-L-G was the lowest among RA-L-G, RA-L, and RA. The study shed light on our understanding of the behavior of RA-L-G. Its diffusion across the body barriers depended on the characteristics of the barrier, such as the protein quantity and types, and the distribution of the polarity. It was significant to research thoroughly.

\section{ACKNOWLEDGEMENTS}

This project was financially supported by the Kangyuan Fund (KYCX201001), Anhui province science and technology special fund project (13Z04013) and the Natural Science Fund of Anhui University of Chinese Medicine (2010zr004A).

\section{DECLARATION OF INTEREST STATEMENT}

The authors report there are no conflicts of interest associated with this publication. The authors alone are responsible for the content. The manuscript has been read and approved by all named authors and the order of authors listed in the manuscript has been approved by all of us.

\section{REFERENCES}

ALLEN, T.M. The use of glycolipids and hydrophilic polymers in avoiding rapid uptake of liposomes by the mononuclear phagocyte system. Adv. Drug Deliv. Rev., v.13, p.285-309, 1994.

AVIRAL, J.; MANISH, K.; CHOURASIA, V.S.; NITIN, K.; JAIN, P.K.; YASHWANT, G.; SANJAY, K.J. Brain-specific delivery of rifampin from lactyl stearate-coupled liposomes via monocarboxylic acid transporters. Am. J. Drug Deliv., v.4, n.1, p.43-49, 2006.

BHALERAO, A.V.; LONKAR, S.L.; DESHKA, S.S.; SHIROLKAR, S.V.; DESHPANDE, A.D. Nasal Mucoadhesive in situ Gel of Ondansetron Hydrochloride. Indian J. Pharm. Sci., v.71, n.6, p.711-713, 2009. 
CHEN, L.; LU, Y.; WU, J.M.; XU, B.; ZHANG, L.J.; GAO, M.; ZHENG, S.Z.; WAND, A.Y.; ZHANG, C.B.; ZHANG, W.W.; LEI, N. Ligustrazine inhibits B16F10 melanoma metastasis and suppresses angiogenesis induced by Vascular Endothelial Growth Factor. Biochem. Biophys. Res. Commun., v.386, n.2, p.374-379, 2009.

COIMBRA, M.; ISACCHI, B.; VAN BLOOIS, L.; TORANO, J.S.; KET, A.; WU, X.; BROERE, F.; METSELAAR, J.M.; RIJCKEN, C.J.; STORM, G.; BILIA, R.; SCHIFFELERS, R.M. Improving solubility and chemical stability of natural compounds for medicinal use by incorporation into liposomes. Int. J. Pharm., v.416, n.2, p.433-442, 2011.

DAN, S.; GUDAS, L.J. Retinoic acid receptor g activates receptor tyrosine kinase Tie1 gene transcription through transcription factor GATA4 in F9 stem cells. Exp. Hematol., v.36, n.5, p.624-641, 2008.

DUDU, V.; ROTARI, V.; VAZQUEZ, M. Sendai virus-based liposomes enable targeted cytosolic delivery of nanoparticles in brain tumor-derived cells. J. Nanobiotechnol, v.10, ID22339792, 9p., 2012.

FRICKER, G.; KROMP, T.; WENDEL, A.; BLUME, A.; ZIRKEL, J.; REBMANN, H.; SETZER, C.; QUINKERT, R.O.; MARTIN, F.; MÜLLER-GOYMANN, C. Phospholipids and Lipid-Based Formulations in Oral Drug Delivery. Pharm. Res., v.27, n.8, p.1469-1486, 2010.

FUJISAWA, S.; ATSUMI, T.; KADOMA, Y. Nuclear magnetic resonance spectroscopic studies of the interaction of methyl methacrylate and ethylene dimethacrylate with phosphatidylcholine liposomes as a model for biomembranes. Biomaterials, v.10, n.1, p.51-55, 1989.

GABIZON, A.; SHMEEDA, H.; BARENHOLZ, Y. Pharmacokinetics of pegylated liposomal doxorubicin. Clin. Pharmacokinet., v.42, n.5, p.419-436, 2003.

GOTO, T.; MORISHITA, M.; NISHIMURA, K.; NAKANISHI, M.; KATO, A.; EHARA, J.; TAKAYAMA, K. Novel mucosal insulin delivery systems based on fusogenic liposomes. Pharm. Res., v.23, n.2, p.384-391, 2006.

HOSLER, B.A.; LAROS, G.J.; GRIPPO, J.F.; GUDAS, L.J. Expression of REX-1, a gene containing zinc finger motifs, is rapidly reduced by retinoic acid in F9 teratocarcinoma cells. Mol. Cell. Biol., v.9, n.12, p.5623-5629, 1989.
HOS SAIN, Z.; KURIHARA, H.; HOSOKAWA, M.; TAKAHASHI, K. Docosahexaenoic acid and eicosapentaenoic acid-enriched phosphatidylcholine liposomes enhance the permeability, transportation and uptake of phospholipids in Caco-2 cells. Mol. Cell Biochem., v.285, p.155-163, 2006.

INOUE, A.; NAGAFUCHI, A.; KIKUCHI, A. Retinoic acid induces discrete Wnt-signaling-dependent differentiation in F9 cells. Biochem. Biophys Res. Commun., v.390, n.3, p.564-569, 2009.

JEMIOLA-RZEMINSKA, M.; PASENKIEWICZ-GIERULA, M.; STRZALKA, K. The behaviour of beta-carotene in the phosphatidylcholine bilayer as revealed by a molecular simulation study. Chem. Phys. Lipids, v.135, n.1, p.27-37, 2005.

JIAO, R.Q.; LI, G.W.; CHIU, J.F. Comparative proteomic analysis of differentiation of mouse F9 embryonic carcinoma cells induced by retinoic acid. J. Cell Biochem., v.113, n.6, p.1811-1819, 2012.

KIM, I.Y.; KANG, Y.S.; LEE, D.S.; PARK, H.J.; CHOI, E.K.; OH, Y.K.; SON, H.J.; KIM, J.S. Antitumor activity of EGFR targeted $\mathrm{pH}$-sensitive immunoliposomes encapsulating gemcitabine in A549 xenograft nude mice. J. Control. Release, v.140, n.1, p.55-60, 2009.

LAING, S.T.; KIM, H.; KOPECHEK, J.A.; PARIKH, D.; HUANG, S.; KLEGERMAN, M.E.; HOLLAND, C.K.; MCPHERSON, D.D. Ultrasound-mediated delivery of echogenic immunoliposomes to porcine vascular smooth muscle cells in vivo. J. Liposome Res., v.20, n.2, p.160$167,2010$.

LAUDET, V.; GRONEMEYER, H. Nuclear receptor factsbook. London: Acedemic Press, 2002. p.113-140.

LIPPMAN, S.; KAVANAUGH, J.; PARADES-ESPINOZA, M.; DELGADILLO-MADRUENO, F.; PARADESCASILLAS, P.; HONG, W.K.; HOLDENER, E.; KRAKOFF, I.H. 13-cis-Retinoic acid plus interpheron alpha 2a: highly active systemic therapy for squamous therapy for squamous cell carcinoma of the cervix (see comments). $J$. Natl. Cancer Inst., v.84, n.4, p.241-245, 1992. 
LIPPMAN, S.; PARKINSON, D.R.; ITRI, L.M.; WEBER, R.S.; SCHANTZ, S.P.; OTA, D.M.; SCHUSTERMAN, M.A.; KRAKOFF, I.H.; GUTTERMAN, J.U.; HONG, W.K. 13-cis-Retinoic acid plus interpheron alpha $2 \mathrm{a}$ : effective combination therapy for advanced squamous cell carcinoma of the skin (see comments). J. Natl. Cancer. Inst., v.84, n.4, p.235-240, 1992.

MANSOUR, M.; MANSOUR, S.; MORTADA, N.D.; ABD ELHADY, S.S. Ocular poloxamer-based ciprofloxacin hydrochloride in situ forming gels. Drug Dev. Ind. Pharm., v.34, n.7, p.744-752, 2008.

MENG-ER, H.; YE, Y.; SHU-RONG, C.; JIN-REN, C.; JIAXIANG, L.; LIN, Z.; LONG, J.; ZHEN-YI, G.W. Use of alltrans-retinoic acid in the treatment of acute promyelocytic leukemia. Blood, v.72, n.2, p.567-572, 1988.

MUINDI, J.; FRANKEL, S.R.; MILLER JR, W.H.; JAKUBOWSKI, A.; SCHEINBERG, D.A.; YOUNG, C.W.; DMITROVSKY, E.; WARRELLJR, R.P. Continuous treatment with all-trans-retinoic acid causes a progressive reduction in plasma drug concentrations: implications for relapse and retinoid "resistance" in patients with acute promyelocytic leukemia. Blood, v.79, n.2, p.299-303, 1992.

MUMPER, R.J.; HOFFMAN, A.S. The stabilization and release of hirudin from liposomes or lipid-assemblies coated with hydrophobically modified dextran. AAPS Pharm. Sci. Tech., v.1, n.1, p.E3-??, 2000.

PANIGRAHI, L.; GHOSAL, S.K.; PATTNAIK, S.; MAHARANA, L.; BARIK, B.B. Effect of permeationenhancers on the release and permeation kinetics of Lincomycin hydrochloride gel formulations through mouse skin. Indian J. Pharm. Sci., v.68, n.2, p.205-211, 2006.

PARTHASARATHY, R.; MEHTA, K. Altered metabolism of all-trans-retinoic acid in liposomeencapsulated form. Cancer Lett., v.134, n.2, p.121-128, 1998.

PARTHASARATHY, R.; SACKS, P.G.; HARRIS, D.; BROCK, H.; MEHTA, K. Interaction of liposome-associated alltrans-retinoic acid with squamous carcinoma cells. Cancer Chemoth. Pharmacol., v.34, p.527-534, 1994.
SUN, S.Y.; LOTAN, R. Retinoids and their receptors in cancer development and chemoprevention. Crit. Rev. Oncol. Hematol., v.41, n.1, p.41-55, 2002.

TIRAND, L.; FROCHOT, C.; VANDERESSE, R.; THORNAS, N.; TRINQUET, E.; PINEL, S.; VIRIOT, M.L.; GUILLEMIN, F.; BARBERI-HEYOB, M. A peptide competing with VEGF165 binding on neuropilin-1 mediates targeting of a chlorin-type photosensitizer and potentiates its photodynamic activity in human endothelial cells. $J$. Control. Release, v.111, n.1-2, p.153-164, 2006.

VIVALDI, A.; MIASAKI, F.Y.; CIAMPI, R.; AGATE, L.; COLLECCHI, P.; CAPODANNO, A.; PINCHERA, A.; ELISEI, R. Re-differentiation of thyroid carcinoma cell lines treated with 5-Aza-20-deoxycytidine and retinoic acid. Mol. Cell Endocrinol., v.307, p.142-148, 2009.

WEINSTEIN, J.N.; LESERMAN, L.D. Liposomes as drug carriers in cancer chemotherapy. Pharmacol. Ther., v.24, n.2, p.207-233, 1984.

WONG, J.L.; KOPPEL, D.E.; COWAN, A.E.; WESSEL, G.M. Membrane hemifusion is a stable intermediate of exocytosis. Dev. Cell., v.12, n.4, p.653-659, 2007.

XIA, H.M.; TANG, C.Y.; GUI, H.; WANG, X.M.; QI, J.L.; WAND, X.Q.; YANG, Y.H. Preparation, cellular uptake and angiogenic suppression of shikonin-containing liposomes in vitro and in vivo. Biosci. Rep., v.33, n.2, p.207-215, 2013.

YOUNG, P.R; TILGHMAN, S.M. Induction of a-fetoprotein synthesis in differentiating F9 teratocarcinoma cells is accompanied by a genome-wide loss of DNA methylation. Mol. Cell Biol., v.4, n.5, p.898-907, 1984.

ZHANG, L.K.; HOU, S.X.; MAO, S.J.; WEI, D.P.; SONG, X.R.; LU, Y. Uptake of folate-conjugated albumin nanoparticles to the SKOV3 cells. Int. J. Pharm., v.287, n.1-2, p.155-162, 2004.

Received for publication on $10^{\text {th }}$ March 2014 Acepted for publication on $02^{\text {nd }}$ July 2015 
